\title{
Effect of syphilitic rabbit sera taken at different periods after infection on treponemal motility, treponemal attachment to mammalian cells in vitro, and treponemal infection in rabbits
}

\author{
G H W WONG,* B STEINER,† AND S GRAVES† \\ From the *Walter and Eliza Hall Institute of Medical Research, Royal Melbourne Hospital, and the \\ †Department of Microbiology, La Trobe University, Bundoora, Victoria, Australia
}

SUMMARY The time course of antibody synthesis during syphilis was studied in experimentally infected rabbits. A rapid antibody response was seen; the rabbits became positive in both the rapid plasma reagin (RPR) test and Treponema pallidum haemagglutination assay (TPHA) by nine days after infection. Treponemal immobilising antibodies were also seen as early as nine days after infection. Antibody inhibition of treponemal attachment to baby rabbit genital organ (BRGO) cells in culture occurred with immune sera taken 30 days after infection but not earlier. When $T$ pallidum was mixed with immune syphilitic rabbit sera taken at different stages of the infection and used to infect normal rabbits the rabbits became partially resistant to $T$ pallidum only when the treponemes were mixed with sera taken at least 30 days after syphilitic infection. This appearance correlated well with the development of antibodies which blocked attachment of $T$ pallidum to host cells. These antibodies may be involved in the resistance to reinfection which develops in syphilis as the disease progresses.

\section{Introduction}

Syphilis occurs both as an acute and a chronic infection. Large quantitites of antibodies are formed and some may be involved in opsonisation ${ }^{1}$ or be directly bacteriocidal for Treponema pallidum. ${ }^{2}$ Several attempts have been made at passive immunisation using immune serum and resulting in partial protection in the recipient rabbits. ${ }^{34}$ Antibodies do interfere with the attachment of $T$ pallidum to mammalian cells ${ }^{56}$ and these factor(s) may be important in eventually producing immunity to the bacterium. Fitzgerald and coworkers have suggested that $T$ pallidum may attach to tissue cells through a mucopolysaccharidase and that antibodies against this enzyme may prevent attachment to tissue cells. ${ }^{7}$ They found that antibodies which reacted with commercial hyaluronidase were present in syphilitic

Address for reprints: Dr G $\mathbf{H ~ W}$ Wong, Walter and Eliza Hall Institute of Medical Research, Post Office, Royal Melbourne Hospital, Victoria 3050, Australia

Accepted for publication 7 January 1983 sera. ${ }^{8}{ }^{9}$ Baseman and Hayes ${ }^{10}$ showed that immune sera contained antibodies against the major surface proteins of $T$ pallidum, presumably including those proteins concerned in treponemal attachment to mammalian cells.

Although the reports quoted above have shown the importance of humoral immunity in syphilis, the treponemes are not eliminated from primary or secondary lesions until a cellular infiltration occurs, mainly of $T$ lymphocytes. ${ }^{11}$ Numerous non-specific antibodies are formed during the course of syphilis which may have nothing to do with immunity. ${ }^{12}$ Some of these may be autoantibodies. For example, antiheart antibodies have been reported in experimental syphilis. ${ }^{13}$ In this study we report the effect of sera collected during syphilitic infection on the attachment of treponemes to cultured mammalian cells in vitro and on infection in vivo. Our aim was to determine when humoral immunity begins and whether antibodies produced early in infection may be involved in enhancement of the disease process by stimulating treponemal attachment to host cells. 


\section{Materials and methods}

\section{SOURCE OF TPALLIDUM}

$T$ pallidum (Nichols) was propagated in adult male rabbits as described ${ }^{14}$ and the treponemes extracted anaerobically. ${ }^{15}$ Eagle's minimal essential medium (EMEM) with $10 \%$ fetal calf serum was used in all experiments, as it had previously been shown to be superior to three other tissue culture media. ${ }^{16}$

\section{RABBIT SERA}

Three rabbits were injected with approximately $5 \times 10^{7}$ viable $T$ pallidum per testis. The rabbits were bled before infection to provide normal rabbit serum (NRS) and periodically thereafter (from 5 to 150 days) to provide syphilitic rabbit sera (SRS). The control rabbit was injected with $5 \times 10^{7}$ heat-killed $T$ pallidum per testis and bled similiarly. Sera were stored separately at $-70^{\circ} \mathrm{C}$ until all were ready for experimental use. They were then sterilised by filtration (Millipore $0.45 \mu \mathrm{m}$ ).

\section{TISSUE CULTURE CELLS}

We had previously examined various cell lines for attachment of $T$ pallidum and the baby rabbit genital organ (BRGO) cell line was superior to others tested. ${ }^{16}$ Thus BRGO cells were used for all experiments. This primary cell line was isolated in our laboratory and maintained in EMEM with $10 \%$ FCS and $10 \mathrm{mmol} / 1$ HEPES without antibiotics at $37^{\circ} \mathrm{C}$. The medium was changed every three days and the confluent monolayers subcultured using phosphate buffered saline containing $0.025 \%$ trypsin (Sigma) and $0.001 \%$ ethylenediamine tetra-acetic acid (EDTA) (Sigma) to remove cells attached to the tissue culture flask.

\section{SEROLOGICAL TESTS}

The rapid plasma reagin (RPR) test (Hynson, Wescott and Dunning, Baltimore) and the $T$ pallidum haemagglutination (TPHA) test (Fujizoki Pharmaceutical Co Ltd, Shinjuku-ku, Tokyo) were performed according to the manufacturer's direction.

The presence of treponemal immobilising antibiotics in the sera was determined by mixing freshly harvested motile treponemes $\left(7 \times 10^{6} / \mathrm{ml}\right)$ with individual SRS at a final serum concentration of $20 \%$ and incubating them microaerophilically at $35^{\circ} \mathrm{C}$ for 24 hours. Examination by dark field microscopy of 100 treponemes at random enabled a percentage motility to be determined for the culture. Since reducing agents interfere with the activity of antibodies in sera $^{17}$ they were excluded from the medium.
ATTACHMENT OF T PALLIDUM TO BRGO CELLS $T$ pallidum $\left(2 \times 10^{7} / \mathrm{ml}\right)$ in serum free medium were mixed with individual SRS for between 30 and 60 minutes at a final serum concentration of $20 \%$. The mixtures were then coincubated with BRGO cells in tissue culture for one hour. Coverslips were then removed from the Leighton tubes and unattached treponemes washed off with medium. The number of treponemes attached per BRGO cell was determined by observing between 30 and 60 BRGO cells at random from duplicate or triplicate tissue culture tubes by dark field microscopy.

SYPHILITIC RABBIT SERUM (SRS) MODIFICATION OF T PALLIDUM VIRULENCE

Different concentrations of $T$ pallidum $\left(10^{3}\right.$ to $\left.10^{7}\right)$ were mixed with individual SRS for between 30 and 60 minutes at a final serum concentration of $50 \%$. The remaining virulence of the $T$ pallidum was determined by intradermal inoculation of $0.1 \mathrm{ml}$ of culture into six sites on the shaved backs of each of two rabbits as described. ${ }^{14}$ The course of the infection was followed and the latent period determined as the time between inoculation and the appearance of induration at the inoculation site. There is an inverse relationship between the latent period of infection and the number of virulent $T$ pallidum remaining in the sample inoculated into the rabbit. ${ }^{12}$

\section{Results}

ANTIBODIES IN SYPHILITIC RABBIT SERA (SRS) AND THE EFFECT OF SRS ON

TREPONEMAL MOTILITY IN CELL FREE MEDIUM Sera taken from nine days after intratesticular infection $\left(5 \times 10^{7}\right.$ treponemes/testis) showed positive results in both the RPR and TPHA tests (fig 1). Sera taken later than 40 days after infection showed the highest titres in both tests.

Immobilising antibodies were present in sera only nine days after infection and reached maximum concentrations by 20 days after infection (fig 2). Thus the rabbits mounted a very rapid humoral immune response against $T$ pallidum in the form of immobilising antibodies. The titre remained high until the last sample was taken 150 days after infection, indicating a long lasting antibody response.

EFFECT OF SRS ON THE ATTACHMENT OF TREPONEMES TO INTACT BRGO CELLS UNDER MICROAEROPHILIC CONDITIONS

Since inhibition of attachment to mammalian cells has been suggested as a possible important role of antibody in syphilis ${ }^{7}$ the effect of individual and 


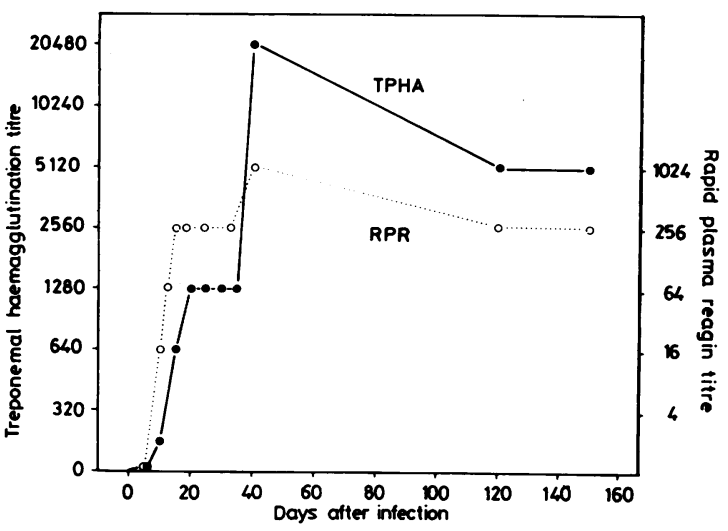

FIG 1 Antibody titres by the rapid plasma reagin (RPR) and Treponema pallidum haemagglutination assay (TPHA) tests in syphilitic rabbit sera (SRS) during syphilitic infection.

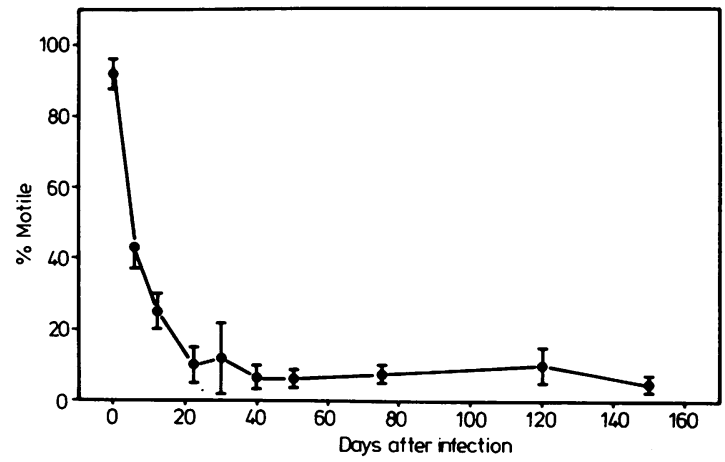

FIG 2 Effect of syphilitic rabbit sera (SRS) on the motility of $T$ pallidum in cell-free medium. Each point is the mean of six samples (SD).

sequential syphilitic rabbit sera on attachment of treponemes to BRGO cells was determined.

The data showed that there was no significant enhancement of treponemal attachment to BRGO cells associated with early SRS when compared with normal serum (fig 3). Sera taken 30 days after infection, however, greatly inhibited treponemal attachment to BRGO cells by up to $70 \%$ compared with normal serum. Since the motility of the treponemes at the time of measurement was approximately $80-90 \%$ the inability of treponemes to attach to BRGO cells was probably not due to a lack of treponemal motility. SRS taken between 30 and 150 days after infection gave similar inhibition, indicating that the factor(s) (presumably antibody) which blocked treponemal attachment to the host cells was continually synthesised.

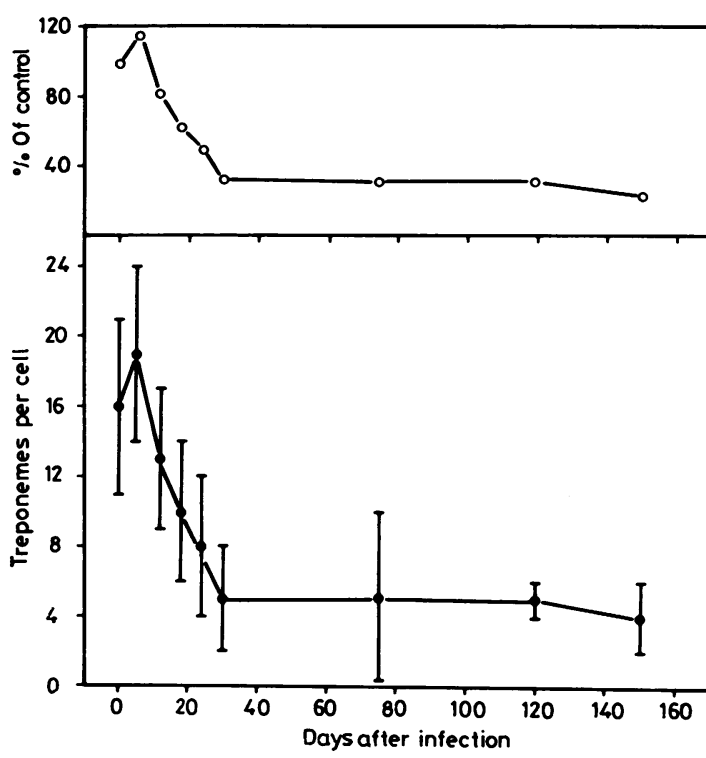

FIG 3 Effect of SRS on the attachment of treponemes to intact baby rabbit genital organ (BRGO) cells under microaerophilic conditions. $\mathrm{O}-\mathrm{O}-$ treponemes per cell in the presence of SRS/treponemes per cell in the presence of normal rabbit serum $\times 100$;

- mean number of treponemes per BRGO cell. Each point is the mean of 30-40 determinations (SD).

EFFECT OF SRS ON TREPONEMAL INFECTION IN VIVO

An attempt was made to correlate the two different antibody responses (antibodies inhibiting treponemal motility and antibodies inhibiting treponemal attachment to the host cells) to actual resistance to infection in the rabbits.

When $10^{7}$ or $10^{6}$ treponemes (prereacted with SRS) were inoculated into the rabbits there were no significant differences in the latent periods of infection (fig 4). A significant difference was observed, however, when $10^{5}, 10^{4}$, or $10^{3}$ treponemes (prereacted with SRS) were inoculated into the rabbits, provided that the sera were taken no earlier than 30 days after infection. The sera reduced the virulence of the $T$ pallidum inoculum as shown by a substantial lengthening of the latent period of infection (fig 4).

\section{Discussion}

These results indicate that antibody present in serum from rabbits infected with $T$ pallidum was probably contributing appreciably to the onset of immunity 


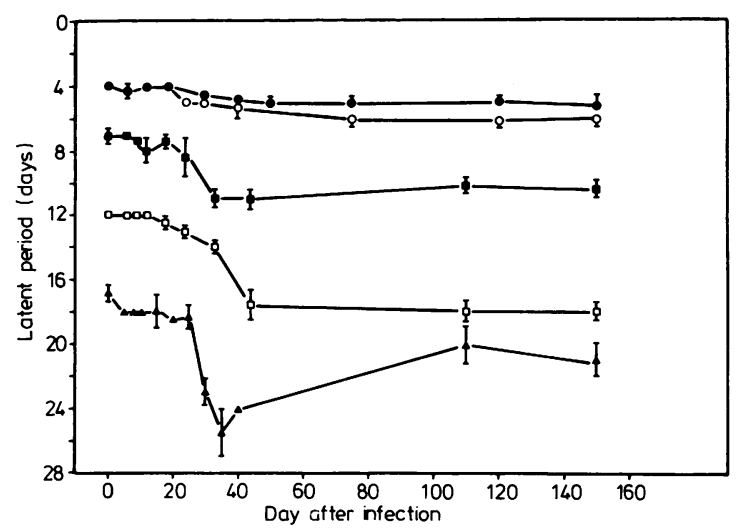

FIG 4 Effect of SRS on infection with $T$ pallidum in vivo. Number of $T$ pallidum injected per site (after reaction with SRS): $\bigcirc-107$; $\bigcirc-106 ; \square-10^{5}$; $\square-10^{4} \Delta-10^{3}$. Each point is the mean of 4-12 lesions on 1-3 rabbits.

by 30 days after infection. Previous published reports have supported a role for antibody in immunity. ${ }^{3412} 18-24$ Rabbits generally start to become resistant to superinfection about two months after infection, although they may not become completely immune until after three months or later. ${ }^{12}$ When the time course of appearance of $T$ pallidum immobilising antibodies and tissue culture cell attachment blocking antibodies were investigated the immobilising antibodies appeared much earlier in infection. They reached appreciable concentrations only nine days after infection and a plateau level by 20 days after infection. The cell-attachment-blocking antibodies appeared much later and did not reach an appreciable concentration until 30 days after infection. Both antibody responses were long lasting and they showed no tendency to decay over the 150 days' observation period. Thus the cell-attachmentblocking antibodies correlated more closely with the onset of immunity in the rabbits than did the immobilising antibodies.

Immobilising antibodies were presumably treponemicidal in vitro but probably not so in vivo. They appeared well before immunity to superinfection developed. At the time immune serum brought about an appreciable reduction in attachment of $T$ pallidum to host cells in the in vitro assay, the same serum was also showing a distinct delaying effect on lesion formation by $T$ pallidum. Although many other antibodies are formed during syphilis this correlation suggests that the same antibodies which block attachment to host cells may contribute appreciably to the onset of immunity.
How $T$ pallidum circumvents this blocking effect of antibody to establish secondary lesions is unknown.

This work was supported by grants from the Australian National Health and Medical Research Council (NH\&MRC), the Utah Foundation, the Heiser Program, the Australian-Britain Society, and Monash University, from whom funds are gratefully acknowledged.

We thank Mr Dick Strugnell for his valuable assistance, and Professor S Faine for the facilities of the department of microbiology, Monash University.

\section{References}

1. Lukehart S, Miller JN. Demonstration of the in vitro phagocytosis of Treponema pallidum by rabbit peritoneal macrophages. J Immunol 1978; 121:2014-24.

2. Nelson RA, Meyer MM. Immobilization of Treponema pallidum in vitro by antibody produced by syphilitic infection. $J$ Exp Med 1949;89:369-93.

3. Graves S, Johnson RC. Effect of pretreatment with Mycobacterium bovis (strain BCG) and immune syphilitic serum on rabbit resistance to Treponema pallidum. Infect Immun 1975; 12: 1029-36.

4. Bishop N, Miller JN. Humoral immunity in experimental syphilis. I The demonstration of resistance conferred by passive immunisation. J Immunol 1976; 117: 191-6.

5. Fitzgerald TJ, Johnson RC, Miller JN, Sykes JA. Characterization of the attachment of Treponema pallidum (Nichols strain) to cultured mammalian cells and the potential relationship of attachment to pathogenicity. Infect Immun 1977; 18: 467-78.

6. Hayes NS, Muse KE, Collier AM, Baseman JB. Parasitism by virulent Treponema pallidum of host cell surfaces. Infect Immun 1977; 17: 174-86.

7. Fitzgerald TJ. Pathogenesis and immunology of Treponema pallidum. Ann Rev Microbiol 1981;35:29-54.

8. Bey RF, Johnson, RC, Fitzgerald TJ. Suppression of lymphocyte response to concanavalin $A$ by mucopolysaccharide material from Treponema pallidum infected rabbits. Infect Immun 1979;26:649.

9. Fitzgerald TJ, Johnson RC. Mucopolysaccharidase of Treponema pallidum. Infect Immun 1979;24:261-8.

10. Baseman JB, Hayes EC. Molecular characterization of receptor binding proteins and immunogens of virulent Treponema pallidum. J Exp Med 1980; 151:573-86.

11. Lukehart S, Baker-Zander SA, Cheri-Lloyd RM, Sell S. Characterization of lymphocyte responsiveness in early experimental syphilis. II Nature of cellular infiltration and Treponema pallidum distribution in testicular lesion. $J$ Immunol 1980;124:461-7.

12. Turner TB, Hollander DH. Biology of treponematoses. WHO Monograph Series, No 35, Geneva: World Health Organisation, 1957.

13. Casavant $\mathbf{C H}$, Wicher $\mathrm{V}$, Wicher $\mathrm{K}$. Host response to Treponema pallidum infection. III Demonstration of autoantibodies to heart in sera from infected rabbits. Int Arch All Appl Immunol 1978; 56: 171-8.

14. Steiner B, McLean I, Graves S. Redox potential and survival of virulent Treponema pallidum (Nichols) under microaerophilic conditions. Br J Vener Dis 1981; 57:295-301.

15. Wong GHW, Steiner B, Graves S. Effects of anaerobic and microaerophilic conditions of extraction and incubation on the survival of Treponema pallidum in vitro. $B r J$ Vener Dis 1982;58: 139-42.

16. Wong GHW, Steiner B, Faine S, Graves S. Factors affecting the attachment of Treponema pallidum (Nichols) to mammalian cells in vitro. Br J Vener Dis 1982;58:21-9.

17. Roitt I. Essential immunology. Oxford; Blackwell Scientific Publications, 1977. 
18. Bishop NH, Miller JN. Humoral immunity in experimental syphilis. II The relationship of neutralizing factors in immune serum to acquired resistance. J Immunol 1976; 117:197-207.

19. Eberson F. Immunity studies in experimental syphilis. Arch Dermatol Syphilol 1921;4:490-511.

20. Graves S. Rate of clearance of virulent Treponema pallidum (Nichols) from the blood stream of normal, Mycobacterium bovis BCG-treated and syphilitic rabbits. Infect Immun 1980;27:264-7.

21. Graves S, Alden J. Limited protection of rabbits against infection with Treponema pallidum by immune rabbit sera. $\mathrm{Br}$ $J$ Vener Dis 1979;55:399-403.
22. Sepetjian M, Salussola D, Trivolet J. Attempt to protect $\stackrel{\mathbb{D}}{\overparen{D}}$ rabbits against experimental syphilis by passive immunization. Br J Vener Dis 1973; 49:335-7.

23. Turner TB, Hardy PH, Newman, B, Nell EE. Effects of passive immunization on experimental syphilis in the rabbit. Johns Hopkins Med J 1973; 133:241-51.

24. Titus RG, Weiser RS. Experimental syphilis in the rabbit; passive transfer of immunity with immunoglobulin $G$ from immune serum. J Infect Dis 1979; 140:904-13. 


\section{Book review}

A book about sexually transmitted diseases. By D Cherniak, 1983. Montreal Health Press, Montreal, Canada. Pp 52.

In 1972 the Montreal Health Press published a "VD Handbook" which was widely distributed throughout North America. Changing social mores as well as advances in the microbiology of infection suggested the need for a replacement publication. In "A book about sexually transmitted diseases" the Montreal Health Press has attempted to provide an up to date and wide ranging discussion of the sexually transmitted diseases (STDs), covering society's attitudes to sex and sexuality, as well as the microbiology and management of individual infections. It has assumed a certain amount of basic knowledge among potential readers, but appears to have occasional doubts about when to simplify medical terminology-for instance, to provide a specimen of urine a woman should "urinate" but to try to prevent urinary tract infection she should "pee frequently and often". The resulting publication is a bit like the curate's egg. It is not helped by its appearance. The magazine format, with pages of typescript relieved by frequent and irrelevant black and white photographs, gives the impression that the finances available for this project were strictly limited.

\section{Corrections}

One of the authors of the paper on syphilis, hepatitis A, hepatitis B, and cytomegalovirus infection in homosexual men in Antwerp (1984; 60:48-51), Dr C-H Coester, undertook the work at the Institut für Medizinische Mikrobiologie, Freie Universität Berlin, Berlin, West Germany as well as at the Institute of Tropical Medicine, Antwerp.
Despite the unpromising appearance, the first few chapters are really rather good. A check list of common symptoms and their possible causes is followed by sections on STDs and sexuality, understanding infections, prevention and self care, dealing with an STD, and basic anatomy. These are all clear and well written and give, along with accurate information, practical and detailed advice. Some of this is applicable only to North America, but most of it would be useful on both sides of the Atlantic. The author deals with basic principles of infection and infectious diseases, and discusses what steps people can usefully take to minimise risks, including changing sexual behaviour. The chapter on "dealing with an STD" describes the medical examination of the patient in some detail with the help of drawings and diagrams. Young people often worry unnecessarily about what will happen to them during the examination, and information given like this can only be reassuring. Occasional lapses into modern sociopolitical jargon in no way diminish the value of these sections.

The success of the first part of the book serves to highlight the failure of the second, in which the author describes the diagnosis and management of individual infections. Some sections, such as the one on gonorrhoea, seem old fashioned and minatory and dwell heavily on the complications of untreated infection. Some confusion arises over diagnostic procedures, such as when the author implies that laparoscopy may be used routinely in the diagnosis of gonorrhoea. There are also numerous microbiological errors, most noticeable in the chapter on chlamydial infection. Chlamydia trachomatis is not an intermediate organism, the clinical appearance of the cervix is not a good indicator of chlamydial infection, and chlamydia should not be assumed to be the cause of urethritis if Gram negative diplococci are not present in a urethral smear.

The other sexually transmitted diseases are dealt with rather more accurately, although treatment regimens of course reflect North American practice. Patients presenting with genital symptoms may have conditions other than STDs; the inclusion of information about vaginitis, prostatitis, and urinary tract infection is helpful.

This small publication contains a great deal of information about sexually transmitted diseases and their implications for the individual and for society. Many medical textbooks contain rather less. Greater medical accuracy would have made "A book about sexually transmitted diseases" even more useful.

J M Hunter
Work for the paper on the effect of syphilitic rabbit serum on treponemal motility, attachment to mammalian cells in vitro, and infection in rabbits $(1983 ; 59$ : 220-4) was undertaken at the Department of Microbiology, Monash University Medical School, Alfred Hospital, Prahan, Victoria, Australia and not at the two institutions cited. 